\title{
Pengetahuan Guru tentang Konstruksi Tes, Penguasaan Materi Pelajaran Sains dengan Reliabilitas Tes Buatan Guru
}

\author{
Sulistianingsih \\ Pendidikan Bahasa Inggris, STKIP Kusuma Negara, Indonesia \\ sulistianingsih1960@stkipkusumanegara.ac.id
}

\begin{abstract}
Abstrak
Penelitian ini bertujuan untuk mendapatkan data empiris hubungan pengetahuan guru tentang konstruksi tes, penguasaan materi pelajaran sains dengan reliabilitas tes buatan guru . Penelitian dilaksanakan di Sekolah Dasar Negeri di Kabupaten Bekasi. Metode yang digunakan dalam penelitian ini adalah metode deskriptif kuantitatif dengan pendekatan korelasional. Pengambilan sampel dilakukan dengan tehnik Multistage random sampling. Penetapan tehnik ini berdasarkan pertimbangan bahwa sampel yang diharapkan sebagai unit analisis dapat menyebar secara merata agar proposional dan representatitif. Instrumen yang digunakan sebagai alat pengumpul data tentang pengetahuan guru tentang konstruksi tes dan penguasaan materi pelajaran sains menggunakan tes dengan bentuk pilihan ganda dan reliabilitas tes buatan guru menggunakan tehnik dokumentasi. Hasil penelitian menyimpulkan hubungan pengetahuan guru tentang konstruksi tes dan penguasaan materi pelajaran sains secara bersama-sama dengan reliabilitas tes buatan guru adalah positif dan sangat signifikan.
\end{abstract}

Kata kunci : konstruksi tes, materi pelajaran, reliabilitas tes

Dikirim: 23 Desember 2019

Direvisi: 07 Januari 2020

Diterima: 07 Januari 2020

\section{PENDAHULUAN}

Guru merupakan komponen utama yang sangat menentukan. Setiap guru dituntut mempunyai kemampuan yang baik untuk membuat soal tes untuk keperluan evaluasi belajar. Didalam proses pembelajaran pentingnya diadakan evaluasi bukan hanya sekedar untuk memenuhi prosedur penilaian saja, tetapi juga evaluasi merupakan kegiatan hasil pembelajaran utuk memperoleh informasi tentang seberapa besar siswa mampu mencapai tujuan pembelajaran yang ditetapkan. Pelaksanaan evaluasi belajar membutuhkan instrument yang dapat menjamin kualitas informasi yang diberikan. Untuk itu diperlukan pengetahuan dan kemampuan guru yang baik dalam mengkonstruksi tes.

Pengetahuan konstruksi tes mengandung pengertian tentang bagaimana menyusun instrument hasil belajar. Djaali \& Muljono (2008) menjelaskan langkahlangkah mengkonstruksi tes meliputi; menetapkan tujuan tes, analisis kurikulum, analisis buku pelajaran, analisis buku pelajaran dan sumber dari materi belajar lainnya, membuat kisi-kisi, penulisan indikator, penulisan soal, reproduksi tes terbatas, ujicoba tes, analisis hasil ujicoba, revisi soal dan merakit soal menjadi tes. Mengkonstruksi tes dengan langkah-langkah yang baik dan tepat, berkaitan dengan ketepatan dalam mengukur (Bloom, 1979). Ketepatan dalam mengukur artinya sesuai, relevan dengan materi yang terkandung dalam kurikulum, sesuai dengan tujuan pembelajaran dan kawasan berpikir yang akan diukur.

Untuk dapat membuat soal yang baik, seorang guru juga harus mempunyai kemampuan untuk menguasai materi pelajaran. Penguasaan materi pelajaran 
merupakan salah satu kemampuan dasar yang harus dimiliki guru, yang terdiri atas kemampuan untuk memahami konsep materi pelajaran,menggeneralisasikan konsep dari setiap topik pelajaran, menyusun konsep secara logis, dan mengembankan kerangka materi pelajaran sesuai dengan konsepnya yang yang terdiri dari pengertian, fungsi, tujuan, ruang lingkup dan bahan kajian mata pelajaran.. Dalam proses penyusunan desain instruksional pemilihan materi pelajaran dilakukan setelah topik dipilih, tujuan instruksional dirumuskan dan alat evaluasi atau tes ditentukan. Hal ini sejalan dengan pendapat Gagne \& Briggs (1992) menjelaskan bahwa disain instruksional adalah keseluruhan proses analisis kebutuhan dan tujuan belajar serta pengembangan teknik mengajar dan materi pengajarannya, termasuk di dalamnya adalah pengembangan paket pelajaran, kegiatan mengajar, uji coba, revisi dan kegiatan mengevaluasi hasil belajar. Pengembangan materi pelajaran akan dapat dilakukan dengan baik apabila guru mampu menyusun materi yang sesuai dengan kompetensi dasar yang harus dikuasai siswa, dapat membuat sekuensa materi pelajaran yang berstruktur, dapat menyusun sistematika dan logika dari urutan materi, dapat mempertimbangkan urutan tingkat kesukarannya serta dapat mengorganisasikannya sehingga dapat menarik dan sesuai dengan kebutuhan siswa. Kemampuan menguasai materi pelajaran secara baik akan menghasilkan soal atau alat ukur yang reliabel dan dapat dipercaya. Soal yang baik disamping dapat memberikan informasi yang tepat tentang siswa yang belum atau sudah memahami materi yang telah diajarkan, dapat membedakan kemampuan dari setiap siswa dan dapat menunjukkan hasil yang konsisten.

Menurut Anastasia \& Urbina (1997), aspek penting yang perlu diperhatikan sebelum tes digunakan untuk mengukur hasil belajar harus memenuhi beberapa syarat, yaitu; (1) Valid, artinya tes harus dapat mengukur apa yang seharusnya diukur, (2) Reliabel, artinya bila digunakan kepada kelompok siswa yang sama beberapa kali dalam waktu yang berbeda akan memberikan hasil yang relative sama, (3) Objektif, artinya tidak dicampuri pengaruh subjektif dari pihak penilai, (4) Seimbang, artinya bahan materi pelajaran tingkat kesukaran dan tujuan harus seimbang, (5) Membedakan, artinya tes harus dapat membedakan prestasi setiap siswa didalam kelompoknya, (6) Norma, artinya hasil tes harus mudah menurut ukuran atau norma tertentu.

Pelaksanaan evaluasi pembelajaran membutuhkan instrumen yang dapat menjamin kualitas informasi yang diberikan. Berbagai instrumen digunakan untuk keperluan tersebut, diantaranya yang paling popular dan paling umum digunakan adalah tes (Arikunto, 2003). Tes hasil belajar dapat dibagi dua bagian, yaitu tes baku dan tes buatan guru. Tes baku berdasarkan sifatnya merupakan tes yang telah menjalani ujicoba sehingga validitas dan reliabilitasnya tidak diragukan lagi, sedangkan tes buatan guru didisain sesuai dengan kebutuhan pembelajaran yang diinginkan, sehingga validitas dan reliabilitasnya belum dapat dipastikan, akibatnya sering terjadi ketidak konsistenan dalam penilaian hasil belajar siswa dan implikasinya berdampak pada aspek-aspek pembelajaran selanjutnya. Ketidak konsistenan terjadi sebagai akibat dari tidak standarnya alat ukur atau tes yang digunakan dan kurang dikuasainya materi pelajaran yang diampu Dengan demikian jelas bahwa kemampuan penguasaan materi pelajaran sangat penting dikuasai oleh guru karena akan berpengaruh terhadap ketepatan pemilihan materi dan sumber belajar dimana materi tersebut diperoleh serta ketepatan dalam mengembangkan instrumen penilaian hasil belajar siswa. 
Soal tes mata pelajaran sains merupakan salah satu soal tes buatan guru yang digunakan untuk menilai penguasaan siswa terhadap materi yang dipelajarinya sesuai dengan tujuan belajar yang sudah ditetapkan, salah satu kegiatan evaluasi hasil belajar yang penting dikuasai guru adalah kemampuan menyusun atau mengkonstruksi tes hasil belajar secara baik dan berkualitas, sehingga dapat mengukur dan memberikan gambaran aspek-aspek perubahan tingkah laku hasil belajar aktual siswa secara benar dan akurat. Maka dalam penyusunannya harus memperhatikan syarat-syarat tes yang baik, tes yang bermutu baik tergantung pada bermutunya soal yang ada didalamnya. Soal yang baik mutunya adalah soal yang dapat memberikan informasi dengan tepat tentang siswa mana yang belum atau sudah memahami materi yang telah diajarkan. Disamping itu soal yang baik harus valid, artinya bahwa setiap alat ukur hanya mengukur satu dimensi atau satu aspek saja sehingga dapat tepat dan reliable atau konsisten hasil pengukurannya, diskriminatif, objektif, praktis, hemat, mudah pengadministrasiannya serta mudah diinterpretasikan hasilnya.

\section{METODE PENELITIAN}

Metode yang digunakan dalam penelitian ini adalah metode deskriptif kuantitatif dengan pendekatan korelasional. Pengambilan sampel dilakukan dengan teknik cluster proposional random sampling, penetapan teknik ini didasarkan pada pertimbangan bahwa sampel yang diharapkan sebagai unit analisis dapat menyebar secara merata dan lebih representatif (Tuckman \& Harper, 2012), dan dalam penelitian ini yang dijadikan sampel adalah seluruh guru Sekolah Dasar Negeri di Kabupaten Bekasi yang tersebar di 33 wilayah Kecamatan yang mengajar di kelas $\mathrm{V}$ pada mata pelajaran sains sebanyak 50 orang.

Instrumen yang digunakan sebagai alat pengumpul data variabel reliabilitas tes sains buatan guru menggunakan tehnik dokumenter dari hasil ulangan tengah semester siswa kelas V mata pelajaran sains yang telah dianalisis oleh guru dengan koefisien reliabilitas sebesar 0,743. Sedangkan data variabel pengetahuan guru tentang konstruksi tes dan penguasaan materi pelajaran sains menggunakan tes dalam bentuk pilihan ganda. Koefisien reliabilitas instrumen pengetahuan guru tentang konstruksi tes sebesar 0,853 dan reliabilitas insrumen penguasaan materi pelajaran sains sebesar 0,864. Uji normalitas menggunakan uji Liliefors dan uji homogenitas menggunakan uji Barlett. Analisis data untuk menguji hipotesis menggunakan tehnik analisis regresi dan korelasi multiple. Keberartia regresi dan keberartian korelasi multiple diuji dengan menggunakan uji F. Hubungan antara variabel dengan dikontrol oleh variabel lain diuji dengan menggunakan tehnik korelasi parsial. Uji signifikan korelasi parsial diuji dengan menggunakan uji t.

\section{HASIL DAN PEMBAHASAN}

\section{Hasil Penelitian}

Sebelum menguji hipotesis statistik dilakukan uji persyaratan analisis data, yang pertama adalah uji normalitas data dengan menggunakan uji Liliefors, yang meliputi dua galat, yaitu; menghasilkan harga $\mathrm{L}_{\mathrm{o}}$ hitung data taksiran 1 ( $\mathrm{Y}-\mathrm{Y}_{1}$ ) sebesar 0,0929 dan $\mathrm{L}_{0}$ hitung data taksiran $2\left(\mathrm{Y}-\mathrm{Y}_{2}\right)$ sebesar 0,1004. Kedua hasil perhitungan menunjukkan bahwa $\mathrm{L}_{\mathrm{o}}$ hitung lebih kecil dari $\mathrm{L}_{\mathrm{o}}$ tabel pada $\mathrm{n}=50$ dengan 
taraf nyata $\alpha=0,01$ sebesar 0,1458 dan $\alpha=0,05$ sebesar 0,1253 . Dengan demikian dapat disimpulkan bahwa data galat $1\left(\mathrm{Y}-\mathrm{Y}_{1}\right)$ dan galat $2\left(\mathrm{YY}_{2}\right)$ berasal dari populasi yang berdistribusi normal. Uji persyaratan analisis data yang kedua adalah pengujian homogenitas variansi dilakukan dengan menggunakan uji Barlett. Pengujian dilakukan terhadap dua kelompok data yaitu; data variansi $\mathrm{Y}$ atas $\mathrm{X}_{1}$ dan data variansi $\mathrm{Y}$ atas $\mathrm{X}_{2}$. Berdasarkan hasil pengujian variansi $\mathrm{Y}$ atas $\mathrm{X}_{1}$ diperoleh $2,483<26,217$, sedangkan variansi $\mathrm{Y}$ atas $\mathrm{X}_{2}$ diperoleh $19,374<22,362$. Dengan demikian disimpulkan bahwa variansi $\mathrm{Y}$ atas $\mathrm{X}_{1}$ dan variansi $\mathrm{Y}$ atas $\mathrm{X}_{2}$ adalah homogen.

Pengujian hipotesis yang pertama yaitu hubungan pengetahuan guru tentang konstruksi tes dengan reliabilitas tes sains buatan guru, dianalisis dengan menggunakan analisis regresi dan korelasi sederhana. Dari hasil perhitungan diperoleh persamaan $\grave{y}=0,224+0,0176 \mathrm{X}_{1}$ adalah signifikan dan linier, hal ini menunjukkan bahwa setiap kenaikan satu unit skor pengetahuan guru tentang konstruksi tes dapat menaikan skor reliabilitas tes buatan guru sebesar 0,0176 pada konstanta 0,224. Sedangkan dari hasil pengujian korelasi diperoleh koefisien korelasi (r) sebesar 0,987 dan koefisien determinasi $\left(\mathrm{r}^{2}\right)$ sebesar 0,974. Setelah diketahui harga koefisien korelasi, dilanjutkan dengan uji keberartian korelasi dengan uji t. Hasil pengujian menunjukkan bahwa thitung sebesar 42,47>2,405 pada $\alpha=0,05$. Dengan demikian hubungan antara pengetahuan guru tentang konstruksi tes dengan reliabilitas tes buatan guru adalah sangat signifikan. Selanjutnya dilakukan pengujian parsial hubungan antara pengetahuan guru tentang konstruksi tes dengan reliabilitas tes sains buatan guru, dikontrol dengan penguasaan materi pelajaran sains, dari hasil pengujian diperoleh nilai koefisien $\mathrm{r}_{\mathrm{y} 1.2}$ sebesar 0,50 dan koefisien determinasi $\mathrm{r}^{2}$ y1.2 sebesar 0,25 .

Koefisien korelasi parsial diuji keberartiannya diperoleh $t_{\text {hitung }}=3,954>2.682$ pada $\alpha=0,05$, hal ini menunjukkan bahwa hubungan antara pengetahuan guru tentang konstruksi tes dengan reliabilitas tes buatan guru dikontrol pengasaan materi pelajaran sains adalah signifikan. Karena hubungan pengetahuan guru tentang konstruksi tes dengan reliabilitas tes buatan guru, baik secara sederhana maupun parsial adalah signifikan, maka dapat disimpulkan bahwa hipotesis nol ditolak, artinya bahwa terdapat hubungan positif antara pengetahuan guru tentang konstruksi tes dengan reliabilitas tes buatan guru.

Pengujian hipotesis yang kedua yaitu hubungan penguasaan materi pelajaran sains dengan reliabilitas tes buatan guru, dianalisis dengan menggunakan analisis regresi dan korelasi sederhana. Dari hasil perhitugan diperoleh persamaan $\grave{y}=0,315+0,0159 \mathrm{X}_{2}$ adalah sangat signifikan dan linier, hal ini menunjukkan bahwa setiap kenaikan satu unit skor penguasaan materi pelajaran sains dapat menaikan skor reliabilitas tes buatan guru sebesar 0,0159 pada konstanta 0,315 . Sedangkan dari hasil pengujian korelasi diperoleh koefisien korelasi (r) sebesar 0,984 dan koefisien determinasi $\left(\mathrm{r}_{2}\right)$ sebesar 0,968 . Setelah diketahui harga koefisien korelasi, dilanjutkan dengan uji keberartian korelasi dengan uji t. Hasil pengujian menunjukkan bahwa $t_{\text {hitung }}$ sebesar 38,086>2,405 pada $\alpha=0,05$. Dengan demikian hubungan antara penguasaan materi pelajaran sains dengan reliabilitas tes buatan guru adalah sangat signifikan. Selanjutnya dilakukan pengujian parsial hubungan antara penguasaan materi pelajaran sains dengan reliabilitas tes buatan guru dengan dikontrol pengetahuan guru tentang konstruksi tes diperoleh nilai koefisien $\mathbf{r}_{\mathrm{y} 2.1}$ sebesar 0,0429 dan koefisien determinasi $r^{2}{ }^{2} 2.1$ sebesar 0,184 . Selanjutnya 
koefisien korelasi parsial diuji keberartiannya dengan menggunakan uji t, dari hasil perhitungan diperoleh $\mathrm{t}$ hitung sebesar 3,257>2,68 pada $\alpha=0,05$, hal ini menunjukkan bahwa hubungan penguasaan materi pelajaran sains dengan reliabilitas tes buatan guru dikontrol pengetahuan guru tentang konstruksi tes, adalah signifikan. Karena hubungan antara penguasaan materi pelajaran sains dengan reliabilitas tes buatan guru, baik secara sederhana maupun secara parsial adalah signifikan maka dapat disimpulkan bahwa hipotesis nol ditolak, artinya terdapat hubungan positif antara penguasaan materi pelajaran sains dengan reliabilitas tes buatan guru.

Pengujian hipotesis ketiga, yaitu hubungan pengetahuan guru tentang konstruksi tes dan penguasaan materi pelajaran sains dengan reliabilitas tes buatan guru, diperoleh persamaan regresi multiple $\grave{y}=0,251+0,0121 \mathrm{X}_{1}+0,00503 \mathrm{X}_{2}$, adalah linier. Uji signifikansi koefisien regresi menggunakan uji $\mathrm{F}$, dari hasil perhitungan diperoleh harga $F_{\text {hitung }}$ sebesar $953,125>\mathrm{F}_{0,01(2 ; 47)}$ sebesar 5,08, artinya regresi $\grave{y}=0,251+0,0121 X_{1}+0,00503 X_{2}$ adalah sangat signifikan. Selanjutnya adalah menguji keeratan hubungan dengan menggunakan analisis korelasi multiple, diperoleh hasil perhitungan $R_{y .12}$ sebesar 0,988 dan koefisien determinasi $R^{2}$.12 sebesar 0,976. Selanjutnya dilakukan uji keberartian terhadap koefisien korelasi multiple dengan menggunakan uji $\mathrm{F}$, diperoleh $\mathrm{F}_{\text {hitung }}$ sebesar 953,125>5,08 pada $\alpha=0,05$. Dengan demikian hubungan antara pengetahuan guru tentang konstruksi tes dan penguasaan materi pelajaran sains dengan reliabilita tes buatan guru, sangat signifikan. Jadi hipotesis nol ditolak, artinya terdapat hubungan positif antara pengetahuan konstruksi tes dan penguasaan materi pelajaran sains dengan reliabilita tes buatan guru.

\section{Pembahasan}

Pengujian hipotesis pertama menunjukkan bahwa, terdapat hubungan positif antara pengetahuan guru tentang konstruksi tes dengan reliabilitas tes buatan guru. Hal ini menunjukkan bahwa semakin tinggi pengetahuan guru tentang konstruksi tes, maka semakin tinggi pula reliabilitas tes sains buatan guru. Secara matematis dapat dinyatakan bahwa pengetahuan guru tentang konstruksi tes berbanding lurus dengan reliabilitas. Hal ini sejalan dengan pendapat Stanley (1992), yang menjelaskan bahwa; reliabilitas tes berhubungan dengan masalah kepercayaan suatu tes, suatu tes dikatakan mempunyai taraf kepercayaan tinggi jika memberikan hasil yang tetap artinya alat ukur tersebut apabila dilakukan pengukuran berulang kali maka akan diperoleh hasil yang sama atau relative sama.

Selain itu sangat terkait pula tes yang dibuat oleh guru dengan pengetahuan guru tentang konstruksi tes, sehingga ruang munculnya pengetahuan guru tentang konstruksi tes relative besar. Artinya pengetahuan guru tentang konstruksi tes memiliki hubungan yang relative sangat besar dengan reliabilitas tes sains buatan guru. Secara statistic telah diperoleh bahwa hubungan tersebut sangat signifikan sehingga harus diperhatikan. Untuk meningkatkan pengetahuan guru tentang konstruksi tes, maka sangat perlu untuk menyediakan sarana dan memberikan kesempatan kepada guru untuk mengembangkan pengetahuannya tentang konstruksi tes. Gronlund (1990), menjelaskan bahwa tes merupakan salah satu prosedur evaluasi yang komprehensip, sistematik dan objektif yang hasilnya dapat dijadikan dasar dalam pengambilan keputusan atas proses pengajaran yang dilakukan guru. Untuk meningkatkan pengetahuan guru tentang konstruksi tes, 
maka sangat perlu untuk menyediakan sarana dan memberikan kesempatan kepada guru untuk mengembangkan pengetahuannya tentang konstruksi tes.

Pengetahuan guru tentang konstruksi tes sangat berguna dalam pembuatan soal. Tes yang baik tergantung pada bermutunya soal yang terkandung didalamnya, yaitu harus valid dan reliable. Soal yang baik mutunya dapat membantu guru dalam meningkatkan pelaksanaan proses belajar mengajar di kelas karena soal tersebut dapat memberikan informasi dengan tepat untuk membedakan setiap kemampuan siswa. Pembuat soal yang baik tidak cukup hanya berlatar belakang menguasi materi yang akan diujikan saja, tetapi harus menguasi teori tes diantaranya adalah mempunyai pengetahuan tentang kaidah penulisan soal atau konstruksi tes yang meliputi; menentukan tujuan tes, menentukan materi pelajaran penting yang akan ditanyakan, menentukan aspek yang akan diukur, membuat kisi-kisi, merumuskan secara tepat indikator kedalam kisi-kisi, menulis soal berdasarkan indicator dan kaidah penulisan soal, membuat pedoman pensekoran serta menentukan penyebaran secara acak. Hal ini di dukung dari hasil pelitian Kemp (1997), Kualitas tes hasil belajar buatan guru pada hakekatnya didasari dan didukung pada tingkat pengetahuan guru tentang konstruksi tes hasil belajar secara memadai. Dengan demikian bahwa suatu soal yang dibuat oleh pembuat soal yang baik, maka hasilnya pun akan lebih baik dan reliable. Ini berarti bahwa untuk mengkonstruksi tes hasil belajar yang baik dan berkualitas tinggi sekurang-kurangnya seorang guru harus memiliki kemampuan pengetahuan dan pemahaman secara teoritis tentang langkahlangkah mengkonstruksi tes. Dari hasil penelitian tersebut memberikan gambaran bahwa pengetahuan guru dalam mengkostruksi soal tes secara baik dan tepat akan menghasilkan alat ukur yang reliabel. Tinggi rendahnya reliabilitas suatu soal tes hasil belajar tergantung pada keteatan dan kecermatan dari setiap item soal yang digunakan sebagai alat ukur.

Pengujian hipotesis kedua menunjukkan bahwa, terdapat hubungan positif antara penguasaan materi pelajaran sains dengan reliabilitas tes buatan guru. Hal ini menunjukkan bahwa semakin tinggi penguasaan materi pelajaran sains, maka semakin tinggi pula reliabilitas tes sains buatan guru. Secara matematis dapat dinyatakan bahwa penguasaan materi pelajaran sains berbanding lurus dengan reliabilitas tes sains buatan guru .

Prosentase variasi reliabilitas tes sains buatan guru yang dapat dijelaskan oleh penguasaan materi pelajaran sains, lebih besar bila dibandingkan dengan prosentase variasi yang dapat dijelaskan oleh pengetahuan guru tentang konstruksi tes. Hal ini konsisten dengan penguasaan materi pelajaran sains yang memiliki sebagian komponen yang harus ada dalam reliabiltas tes buatan guru. Salah satu ciri soal yang bermutu baik harus handal dan konsisten pengukurannya serta dapat membedakan setiap kemampuan siswa. Semakin tinggi kemampuan siswa dalam memahami materi yang telah diajarkan, maka semakin tinggi pula peluang menjawab benar suatu soal yang menanyakan materi yang telah diajarkan. Prosentase variasi reliabiilitas tes sains buatan guru yang dapat dijelaskan oleh penguasaan materi pelajaran sains, lebih besar bila dibandingkan dengan prosentase variasi yang dapat dijelaskan oleh pengetahuan guru tentang konstruksi tes. Hal ini konsisten dengan penguasaan materi pelajaran sains yang memiliki sebagian komponen yang harus ada dalam reliabiltas tes buatan guru. Penguasaan materi pelajaran menurut Gagne \& Briggs (1992), adalah kemampuan atau merupakan daya untuk melakukan suatu tindakan atau perbuatan yang hasilnya dapat diamati 
dari suatu usaha belajar serta melalui latihan dalam bidang tertentu dalam hal ini materi ajar. Dalam menyusun isi dan urutan bahan ajar, pengembangan materi pelajaran akan dapat dilakukan dengan baik apabila seorang guru mampu menguasai materi pelajaran, dapat menyusun materi yang sesuai dengan kompetensi yang akan dicapai, dapat membuat sekuensa materi pelajaran yang berstruktur, dapat menyusun sistimatika dan logika dari urutan materi pelajaran, dapat mempertimbangkan urutan tingkat kesukaran serta dapat mengorganisasikannya sehingga dapat menarik dan sesuai dengan kebutuhan siswa. Salah satu ciri soal yang bermutu baik harus handal dan konsisten pengukurannya serta dapat membedakan setiap kemampuan siswa. Semakin tinggi kemampuan siswa dalam memahami materi yang telah diajarkan, maka semakin tinggi pula peluang menjawab benar suatu soal yang menanyakan materi yang telah diajarkan.

Untuk mendapatkan soal yang bermutu baik seorang guru harus mampu menguasai materi pelajaran, antara lain yaitu: dapat menentukan secara tepat dan proposional dari materi pelajaran yang akan ditanyakan, menentukan aspek yang akan diukur dan merumuskan indicator secara tepat. Hal ini penting dikuasai karena guru tidak mungkin menanyakan semua materi yang telah diajarkan dalam waktu yang terbatas. Hal ini senada denga Safari (2008), yang menjelaskan bahwa, dalam penyusunan soal yang baik tidak cukup hanya berlatar belakang penguasaan soal yang diujikan saja, tetapi juga harus menguasai materi pelajaran.Hal ini juga senada dengan hasil penelitian Santoso (2008), yang menunjukkan bahwa terdapat korelasi yang positif antara penguasaan materi pelajaran dengan kualitas soal tes hasil belajar. Dari hasil penelitian ini nampak bahwa salah satu factor yang menentukan kualitas tes hasil belajar adalah kemampuan penguasaan materi pelajaran yang diajarkannya.

Ada beberapa hal yang perlu diperhatikan dalam memilih materi pelajaran yang akan ditanyakan yaitu: materi pelajaran merupakan pendalaman dari materi yang sudah dipelajari sebelumnya, materi pelajaran tersebut merupakan materi pokok yang harus dikuasai siswa, materi pelajaran diperlukan untuk mempelajari dan memahami materi dari pelajaran lain, berkesinambungan dan memiliki nilai terapan dalam kehidupan sehari-hari dan dapat diukur dengan menggunakan bentuk soal yang sudah dirancang. Tes yang reliabel adalah tes yang bermutu baika yaitu soal yang dapat membantu guru dalam meningkatkan pelaksanaan proses pembelajaran di kelas, karena soal tersebut dapat memberikan informasi dengan tepat untuk dapat membedakan kemampuan siswa. Semakin tinggi kemampuan siswa memahami materi yang telah diajarkan, maka akan semakin tinggi pula peluang menjawab benar suatu soal atau sebaliknya.

Pengujian hipotesis ketiga menunjukkan bahwa setiap kenaikan skor pengetahuan guru tentang konstruksi tes dan penguasaan materi pelajaran sains, diikuti oleh naiknya skor reliabilitas tes sains buatan guru atau semakin tinggi pengetahuan guru tentang konstruksi tes dan penguasaan materi pelajaran sains, maka semakin tinggi reliabilitas tes sains buatan guru. Secara matematis dapat dinyatakan bahwa pengetahuan guru tentang konstruksi tes dan penguasaan materi pelajaran sains berbanding lurus dengan reliabilitas tes sains buatan guru.

Maka dengan demikian korelasi pengetahuan guru tentang konstruksi tes dengan reliabilitas tes sains buatan guru, berkorelasi tinggi. Sedangkan korelasi penguasaan materi pelajaran sains dengan reliabilitas tes sains buatan guru, 
berkorelasi tinggi. Jadi dengan korelasi pengetahuan guru tentang konstruksi tes dengan reliabilitas tes sains buatan guru lebih kuat dibandingkan dengan korelasi penguasaan materi pelajaran sains dengan reliabilitas tes sains buatan guru Secara bersama-sama. Hal ini didukung oleh Silverius (2014), menjelaskan bahwa terdapat pengaruh yang signifikan antara pengetahuan dalam penyusunan soal dan kemampuan menguasai materi pelajaran dengan kualitas tes buatan guru. Proses pembelajaran akan berjalan efektif bila guru mendapat umpan balik dari siswa mengenai materi pelajaran dan cara mengajarnya. Umpan balik dapat diperoleh melalui tes hasil belajar. Untuk mendapatkan tes yang baik tidak saja dibutuhkan kemampuan untuk mengkonstruksi tes dengan kriteria yang dipersyaratkan tetapi juga penguasaan materi pelajaran, sehingga guru tahu apa yang diajarkan dan apa yang akan diujikan. Berdasarkan logika berpikir tersebut, maka semakin baik guru dalam mengkonstruksi tes dan menguasai materi pelajaran maka akan semakin reliabel soal tes yang dibuatnya.

Setelah menganalisa hasil penelitian, maka dapat ditarik beberapa kesimpulan sebagai berikut: Pertama, terdapat hubungan positif dan signifikan antara pengetahuan guru tentang konstruksi tes dengan reliabilitas tes sains buatan guru, yang bersifat searah, artinya gerak satu variabel akan diikuti oleh variabel yang lainnya. Dengan kata lain apabila pengetahuan guru tentang konstruksi tes memiliki skor yang tinggi maka skor reliabilitas tes sains buatan guru akan tinggi pula. Sebaliknya, jika skor pengetahuan guru tentang konstruksi tes rendah maka reliabilitas tes sains buatan guru akan rendah pula. Kedua, terdapat hubungan positif dan signifikan antara penguasaan materi pelajaran sains dengan reiabilitas tes sains buatan guru yang bersifat searah, artinya gerak satu variabel akan diikuti variabel lainnya. Dengan kata lain apabila penguasaan materi pelajaran sains memiliki skor yang tinggi maka skor reliabilitas tes sains buatan guru akan tinggi pula. Sebaliknya jika skor penguasaan materi pelajaran sains rendah maka reliabilitas tes sains buatan guru rendah pula. Ketiga, terdapat hubungan positif dan signifikan antara pengetahuan guru tentang konstruksi tes dan penguasaan materi pelajaran secara bersama-sama dengan reliabilitas tes sains buatan guru artinya gerak satu variabel secara bersama-sama akan diikuti oleh variabel lainnya. Dengan kata lain apabila pengetahuan guru tentang konstruksi tes dan penguasaan materi pelajaran sains secara bersama-sama memiliki skor yang tinggi maka skor reliabilitas tes sains buatan guru akan tinggi pula. Sebaliknya, jika skor pengetahuan guru tentang konstruksi tes dan penguasaan materi pelajaran sains secara bersama-sama rendah maka reliabiltas tes sains buatan guru rendah pula.

\section{REFERENSI}

Anastasi, A., \& Urbina, S. (1997). Psychological testing. New Jersey: Pearson Education.

Arikunto, S, (2003). Dasar-dasar Evaluasi Pendidikan. Jakarta: Bumi Aksara.

Bloom, B. S., (1979). Taxonomy of Educational Objectives. London: Longman Ltd.

Djaali, H., \& Muljono, P. (2008). Pengukuran dalam bidang pendidikan. Jakarta, Grasindo.

Gagne, R. M., \& Briggs, L. J. (1992). Principles of instructional design. Orlando: Harcout Brace and Company. 
Kemp, J. E. (1997). Instructional Design: A Planfor Unit and Course Development. California: Fearon Published

Safari. (2008). Pengujian dan Penilaian Bahasa Dan Sastra Indonesia. Jakarta: Roda Pengetahuan.

Santoso. (2008). Kontribusi Penguasaan Materi Bahasa Inggris Dengan Kualitas Hasil Belajar Siswa (Penelitian Kemampuan Guru SMA Negeri Malang) [PDF file]. Retrieved from http://eprint.undip.ac.id/12368/.

Silverius, S. (2014). Evaluasi Hasil Belajar Umpan Balik. Jakarta: Grasindo.

Tuckman, B. W., \& Harper, B. E. (2012). Conducting Educational Research. USA: Rowman \& Littlefield Publishers. 